\title{
HEPATO-RENAL SYNDROME: ETIOPATHOGENESIS, DIAGNOSIS AND TREATMENT
}

\author{
Jelena Nešić ${ }^{1}$, Nenad Zornić2, Vesna Rosić ${ }^{3}$, Dejan Petrović ${ }^{4}$ \\ ${ }^{1}$ Clinic for Internal Medicine, Clinical Centre "Kragujevac", Kragujevac \\ ${ }^{2}$ Department of anaesthesiology and reanimatology, Clinical Centre "Kragujevac", Kragujevac \\ ${ }^{3}$ Department of Histology, Faculty of Medical Sciences, University of Kragujevac \\ ${ }^{4}$ Clinic for Urology and Nephrology, Clinical Centre "Kragujevac", Kragujevac \\ HEPATO-RENALNI SINDROM: \\ ETIOPATOGENEZA, DIJAGNOZA I LEČENJE \\ Jelena Nešić ${ }^{1}$, Nenad Zornić 2 , Vesna Rosić ${ }^{3}$, Dejan Petrović ${ }^{4}$ \\ ${ }^{1}$ Klinika za internu medicine, KC “Kragujevac”, Kragujevac \\ ${ }^{2}$ Centar za anesteziologiju i reanimaciju, KC "Kragujevac", Kragujevac \\ ${ }^{3}$ Katedra za Histologiju i embriologiju, Fakultet medicinskih nauka, Univerziteta u Kragujevcu \\ ${ }^{4}$ Klinika za urologiju i nefrologiju, KC “Kragujevac”, Kragujevac
}

\begin{abstract}
Hepatorenal syndrome (HRS) involves reversible renal failure in patients with advanced cirrhosis or acute liver failure. The aim of the study was to determine the pathogenetic mechanisms of the development of hepatorenal syndrome and to emphasise the clinical importance of early detection and timely treatment of patients with this condition. The one-year incidence rate of hepatorenal syndrome in patients with liver cirrhosis is $18-20 \%$. The risk factors for the development of hepatorenal syndrome include the following: spontaneous bacterial peritonitis, gastrointestinal bleeding, nephrotoxic drugs, diuretics, non-steroidal anti-inflammatory drugs, and hyponatraemia. The primary plan of treatment is a liver transplantation, while a secondary plan of treatment is the use of a vasoconstrictor in conjunction with albumin. Early diagnosis and prompt appropriate treatment can significantly reduce the mortality rate of patients with hepatorenal syndrome.
\end{abstract}

Key words: liver, kidney, risk factors, liver transplantation

\section{SAŽETAK}

Hepatorenalni sindrom (HRS) predstavlja reverzibilnu bubrežnu insuficijenciju kod bolesnika sa uznapredovalom cirozom ili akutnom insuficijencijom jetre. Cilj rada je da utvrdi patogenetske mehanizme razvoja hepatorenalnog sindroma i da ukaže na klinički značaj ranog otkrivanja $i$ pravovremenog lečenja bolesnika sa hepatorenalnim sindromom. Jednogodisnja stopa hepatorenalnog sindroma kod bolesnika sa cirozom jetre iznosi 18-20\%. U faktore rizika za nastanak hepatorenalnog sindroma spadaju: spontani bakterijski peritonitis, gastrointestinalno krvarenje, nefrotoksični lekovi, diuretici, nesteroidni antiinflamatorni lekovi, hiponatriemija. Primarni plan lečenja je transplantacija jetre, dok sekundarni plan lečenja je primena vazokonstriktora u kombinaciji sa albuminima. Rano dijagnostikovanje i pravovremena primena odgovarajućeg lečenja znatno smanjuju stopu smrtnosti bolesnika obolelih od hepatorenalnog sindroma.

Ključne reči: jetra, bubreg, faktori rizika, transplantacija jetre

\section{ABBREVIATIONS}

HRS - hepatorenal syndrome
NO - nitric oxide
RAAS - renin - angiotensin - aldosterone system

SBP - spontaneous bacterial peritonitis

TIPS - transjugular intrahepatic portosystemic shunt

\section{INTRODUCTION}

Hepatorenal syndrome (HRS) refers to reversible renal failure in patients with advanced cirrhosis or acute liver failure (1-6). It can occur rapidly, over 48 hours, or gradually, over a week or two (7-9). The incidence of HRS in patients with cirrhosis of the liver is approximately $18-20 \%$ during the first year, and it increases to $39 \%$ after 5 years $(10,11)$. HRS may occur spontaneously. In half of the patients with HRS, one or more pre-

cipitating factors can scause HRS, including: bacterial infection, particularly spontaneous bacterial peritonitis (57\%), gastrointestinal bleeding (36\%) and therapeutic paracentesis $(7 \%)(10,12)$. HRS is the most common complication in patients with liver cirrhosis and ascites, and there areits morbidity and mortality rates are high (13-15). Only $3.5 \%$ of patients recover spontaneously from hepatorenal syndrome (3). 
Even if its pathogenesis is not fully explained, the main etiological factor is renal hypoperfusion, which results from vasodilatation and vascular resistance in the lesser splanchnic region (4).

It is interesting that the histological appearance of the kidneys is normal in hepatorenal syndrome, which makes this syndrome a unique pathophysiological disorder of the renal circulation in which there are no elements of morphological kidney damage. Therefore, the renal insufficiency is reversible, and it occurs from functional disorder of the circulation, rather than direct morphological kidney damage, as evidenced by the fact that after liver transplantation, kidney function returns to normal.

The type of HRS predominantly determines the outcome and survival of patients. There are two types of hepatorenal syndrome, type 1 and type 2; the two types are pathophysiology similar, while the clinical features and prognosis vary (16). Hepatorenal syndrome type 1 is characterised by rapid, progressive reduction of the effective circulating volume, which is due to the extreme intestinal arterial vasodilation and a decrease in the cardiac output, which is usually preceded by spontaneous bacterial peritonitis. Hepatorenal syndrome type 2 is caused by a gradual and stable reduction of the glomerular filtration rate and it is common in patients with relatively intact liver function. As defined by Salerno et al, HRS type 1 is indicated by a laboratory increase in the serum creatinine above $133 \mathrm{mmol} / \mathrm{l}(1.5 \mathrm{mg} / \mathrm{dl})$ in patients with liver cirrhosis and ascites in the absence of hypovolemic shock, nephrotoxic drugs or primary kidney disease. In type 2 HRS, the serum creatinine is doubled (over 100\%) compared to baseline to more than 221 $\mathrm{mmol} / \mathrm{l}(2.5 \mathrm{mg} / \mathrm{dl})(17,18)$. The increase in the serum creatinine can be acute (type 1 HRS) or gradual (type 2 HRS) (19).

Type 2 HRS is more common in clinical practice than type 1 (20). The expected survival rate for type $1 \mathrm{HRS}$ is approximately 2 weeks, while this period is much longer, approximately 6 months, in type 2 HRS (12). While the survival of the patients with type 2 is considerably longer than forthat of patients with type 1 , it is still shorter than for patients who do not have HRS.

\section{Pathogenesis}

Although HRS as a clinical entity was first described 50 years ago, the pathogenesis of this syndrome has not yet been fully characterizised (21). HRS is the final stage of a series of disturbances in the kidney and is accompanied by deterioration of liver function and portal hypertension (21).

The main feature of hepatorenal syndrome is renal vasoconstriction, although the pathogenesis of this process has not been previously explained. A number of mechanisms are associated with this syndrome, including increased activity of systemic and renal vasoconstriction, leading to reduced renal perfusion and a decrease in the glomerular filtration rate. On the basis of the disturbance, a vasodilation splanchnic circulation is expressed, reducing the effective circulating volume and hypotension with consequent activation of the sympathetic system, renin-angiotensin system, and vasopressin (22). Entotelin, adenosine and leukotriene L4 also play an important role in addition to being the main vasoconstrictors (renin - angiotensin - aldosterone composition (RAAS) and the sympathetic nervous system). All of these vasoconstrictors lead to renal vasoconstriction. Local formation of kidney vasodilators, mainly prostaglandins and nitric oxide (NO), is weakened $(12,23,24)$.

The splanchnic circulation is resistant to vasoconstrictors for the continuous production of local vasodilators such as NO. In the splanchnic circulation, the creation of vasodilators is maintained at a high level, and the response to the effects of endogenous vasoconstrictor systems becomes weaker (1-6).

\section{The clinical picture}

HRS has non-specific symptoms and signs, which makes early identification and diagnosis more difficult. Because most patients with HRS have chronic liver disease, it is important to note the signs, including the following: palmar erythema, a leukonychia, asterixis, and clubbing fingers (hand), icterus sclera, spider nevi, foetor hepaticus, xanthelasma, and gynecomastia (head), caput medusae, hepatosplenomegaly, ascites, and paraumbilical herniation (abdomen), pubic hair loss and atrophic testes (genitals), and, and peripheral oedema and clubbing fingers (extremities).

The symptoms and signs of disease in HRS and chronic liver diseases overlap, and they include the following: arterial hypotension (middle arterial pressure values of approximately $80 \mathrm{mmHg}$ or lower), oliguria, tachycardia, jaundice, hepatic encephalopathy, and ascites (25).

In the final stage of HRS, the patient is comatose and hypotensive with a urine output of less than $100 \mathrm{ml}$ in 24 hours. In more than $80 \%$ of the patients, death occurs in a few days to a maximum of 12 weeks $(12,21,26)$. The cause of death is a terminal defect of the liver cells rather than renal failure (21).

Laboratory analyses show hyponatraemia, serum levels below $130 \mathrm{mmol} / \mathrm{l}$ with an incidence of approximately $21.6 \%$ for HRS (27). Patients with liver cirrhosis and hyponatraemia are at high risk of developing HRS (10). Several studies have shown a positive correlation between hyponatraemia and hepatic encephalopathy. A low level of serum sodium and increased level of amonium lead to major electroencephalographic changes, resulting in the development of hepatic encephalopathy (28). Hyponatraemia predicts poor prognosis, and the median survival in patients with liver transplantation is less than 6 months (29). Hyponatraemia affects the patients' quality of life. A recent study has shown that a low level of $\mathrm{Na}^{+}$is an independent predictive factor of the quality of life of patients with cirrhosis (30). 


\section{Diagnosis}

The diagnosis of the disease is sometimes extremely difficult due to the lack of a specific test or pathognomonic marker of the disease. The diagnosis of hepatorenal syndrome is based on the exclusion of other diseases that reduce the rate of glomerular filtration in the absence of other causes of chronic renal disease.

Table 1 Criteria for the diagnosis of HRS - International Ascites Club -2007 (17):

- Cirrhosis of the liver with ascites

- Creatinine in the serum > $1.5 \mathrm{mg} / \mathrm{dL}(133 \mathrm{mmol} / \mathrm{l})$

- Absence of shock, absence of current or recently completed treatment with nephrotoxic drugs, absence of parenchymal kidney disease and fluid loss

- No stable improvement in the renal function after at least 2 days $(48 \mathrm{~h}$ ) (reduction of the serum creatinine of less than $1.5 \mathrm{mg} / \mathrm{dl}$ or an increase in the creatinine clearance of more than $40 \mathrm{ml} /$ per min) after the completion of a diuretic and after the application of albumin and an intravenous (iv) solution $(1 \mathrm{~g} / \mathrm{kg} \mathrm{TT} / \mathrm{a}$ day dose of albumin up to a maximum of $100 \mathrm{~g} / \mathrm{a}$ day),

- Proteinuria of less than $500 \mathrm{mg}$ per day

- Normal renal ultrasound findings

- The number of red blood cells in the urine is less than 50 , and microhematuria

\section{Risk factors}

If there are precipitating factors that lead to the development of HRS, it is necessary to eliminate them in a timely fashion. These factors include spontaneous bacterial peritonitis, gastrointestinal bleeding, nephrotoxic drugs, diuretics, non-steroidal anti-inflammatory drugs, and hyponatraemia. The most important risk factor for the development of HRS is bacterial infection, particularly spontaneous bacterial peritonitis $(31,32)$. HRS develops in approximately $30 \%$ of patients who have SBP (31). The treatment of SBP includes infusion of albumin and antibiotics, reducing the risk of developing HRS and improving survival (31). Potassium-sparing diuretics should be excluded from treatment to avoid hyperkalaemia (33).

\section{Liver transplantation}

Liver transplantation is the method of choice for type 1 and type $2 \mathrm{HRS}$; the survival rate is approximately $65 \%$ for type 1 and $80 \%$ for type $2(20,34)$. A slightly lower survival rate is noted compared to patients with cirrhosis without HRS because of the presence of renal insufficiency, which represents a major predictor of an unfavourable outcome after liver transplantation $(35,36)$.

Over the past century, liver transplantation has been successfully performed in only a few patients with HRS be- cause most patients died before transplantation due to the rapid disease progression in type 1 HRS.

In a prospective study of 15 patients with HRS type 1 who were candidates for transplantation, 12 patients had contraindications to liver transplantation, and the remaining three died while waiting for transplantation (37).

Without liver transplantation, the HRS prognosis is unfavourable. A study was conducted on 68 type 1 HRS patients who were candidates for a liver transplantation. All patients were treated medically with various combinations of the following: albumin, vasopressors, midodrine, octreotide and haemodialysis. The results showed that the median survival was 13 days for the entire group. Early treatment can increase the survival rate of HRS (38).

The main problem with liver transplantation is the long waiting time and short-term survival of these patients. The one-year and four-year survival rates of patients with HRS who undergo liver transplantation are $71 \%$ and $60 \%$, whereas in patients with liver transplantation without HRS, the oneyear and four-year survival rates are 83 and 70\% (39). However, $10 \%$ of patients require dialysis after transplantation (1).

A new approach to the treatment is suggested, the socalled "Treatment of bridge healing ", which is meant to reduce the number of patient deaths during the wait for liver transplantation. The treatment of bridge healing "consists of a combination of terlipressin 4-6 mg/a day with albumin, which enables to bridge, that is to overcome the period of waiting until liver transplantation" $(40,41)$. However, few patients with HRS undergo transplantation.

\section{The correction of renal hypovolaemia}

Given that HRS lab values are similar to those observed pre-renal azotaemia, previous attempts were made to begin treating hypovolaemia with infusions (saline or dextran). Because this form of treatment was not successful, it was abandoned. Today, the main way that hypovolaemia is corrected is by increasing albumin to $50 \mathrm{~g} /$ day in combination with administering vasoconstrictors (42).

\section{Drug treatment}

Many medications have been used to treat hepatorenal syndrome in the past, but vasoconstrictors have had thebest effects. These drugs cause vasoconstriction of blood vessels of the splanchnic region and reperfusion of the renal arteries $(43,44)$. The most common side effects of treatment are cardiovascular or ischemic complications, which occur with an average frequency of $12 \%$ in treated patients $(24,45)$. Various types of studies have tested the efficacy of vasoconstrictors.

A retrospective study was performed on 59 patients with HRS type 1; after a combination of vasoconstrictor and albumin was administered, there was a greater than $10 \mathrm{mmHg}$ increase in middle arterial pressure. The respondents had improved treatment efficacy, a favourable response to liver transplantation and a reduced need for dialysis. (46). 
A meta-analysis of six randomised controlled studies in which patients who had been on various vasoconstrictor drugs in combination with or without albumin were monitored. The authors reported that mortality was reduced by $18 \%$ compared to the control groups of people who did not undergo therapy with vasoconstrictors (15). A meta-analysis of four randomised controlled studies showed that patients who were treated with terlipressin with or without albumin were 3.8 times more likely to recover (heal) from HRS and 2 times more likely to have improved renal function compared to patients who were not treated with vasoconstrictors (15). Despite all of these encouraging results regarding the use of vasoconstrictors with or without albumin, these drugs are effective in reducing mortality for 15 days, without significant effects at 1,3 , and 6 months. Vasoconstrictor therapy is effective in 46 to $48 \%$ of patients (15).

Vasoconstrictors are analogues to vasopressins (ex. Terlipresin), analogues to somatostatins (Octreotide), and agonists of the $\alpha$-adrenergic receptors (Midodrine) in combination with albumin infusion $(43,44)$.

Terlipressin is the most effective and most widely used vasoconstrictor. Terlipressin, vasopressin's analogue, acts on the two types of receptors, V1 and V2. V1 receptors are found in the smooth muscles of blood vessels, and through these receptors, vasopressin causes vasoconstriction. V2 receptors are found in the renal tubules, and, through these receptors, this hormone acts as an antidiuretic. Terlipressin has agonistic effects on V1 receptors and partial agonistic effects on the renal V2 receptors. It affects the V1 receptors of the intestinal vasculature, causing dominant vasoconstriction in the mesenteric circulation compared to the renal arteries. However, its effects on the serum concentrations of $\mathrm{Na}$ are controversial. Terlipressin is most commonly used in Europe because it reduces the chances of ischemic complications.

Today, terlipressin, according to general recommendations, represents the most effective vasoconstrictor in the treatment of HRS type 1 . There are reports on the significantly higher efficacy of combination therapy with terlipressin and albumin $(14,45)$., Although this combination is also used in type 2 HRS, there is still limited information on the use of terlipressin on these patients $(47,48)$.

The protocol for the treatment with terlipressin involves an initial dose of $0.5-1 \mathrm{mg} / 4-6 \mathrm{~h}$ via i.v. or continuous i.v. infusion $2 \mathrm{mg} /$ day. If the creatinine level has not fallen by $25 \%$ on the third day of treatment, the dose is increased to $2 \mathrm{mg} / 4 \mathrm{~h}$ or $12 \mathrm{mg} /$ day by continuous intravenous infusion. In the case of failure to maintain a central venous pressure of $10-15 \mathrm{~mm} \mathrm{H}_{2} \mathrm{O}$, the initial dose of albumin is $1 \mathrm{gr} / \mathrm{kg}$ for two days up to a maximum $100 \mathrm{~g} /$ day (23).

Treatment continues until there is no improvement in the laboratory values, which is normally not more than 2 weeks. In almost $59 \%$ of patients with type 1 HRS, there is complete (reduction of serum creatinine $<133 \mathrm{mmol} / \mathrm{l}$ ) or partial (reduction of serum creatinine $>50 \%$ with values $>$ $133 \mathrm{mmol} / \mathrm{l}$ ) healing (49).
Alternative vasopressors are rarely used because they have not been adequately investigated, and there are few studies on these drugs (50).

Alpha-adrenergic agonists have an advantage over terlipressin because their price is lower, but they are less efficient. Midodrine is an alpha agonist with that has an advantage of being the only agent that can be administered orally ( 2.5 to $75 \mathrm{mg} / 8 \mathrm{~h}$ ).

Norepinephrine is applied by continuous infusion at a dose of $0.5-3 \mathrm{mg} / \mathrm{h}$ according to the level of arterial blood pressure. Unfortunately, the number of patients treated with noradrenaline is small, and there are no randomised comparative studies for assessing its efficacy.

Previously, dopamine and prostaglandins were posited as potential vasodilators in the literature, but their application has not been accepted in clinical practice.

\section{Transjugular intrahepatic portosystemic shunt}

A transjugular intrahepatic portosystemic shunt (TIPS) is a percutaneously created connection within the liver parenchyma between the portal and systemic circulation. A TIPS is set to reduce the portal pressure in patients with complications that are associated with portal hypertension.

The aim of a TIPS placement is to redirect the blood flow in the hepatic veins, reducing the pressure gradient between the portal and systemic circulation.

According to currentthe present study, the use of a TIPS is effective in the treatment of ascites and leads to improvement in renal function. It can be used as a bridge therapy while patients are waiting for a liver transplantation $(51,52)$.

\section{CONCLUSION}

HRS is one of the most serious complications of liver disease and is most common in patients with decompensated liver cirrhosis. The survival time of these patients is short, and spontaneous recovery is very rare. The only therapy for HRS is liver transplantation. The aim of new studies will be the search for better diagnostic and therapeutic procedures.

Acknowledgments: The authors would like to express their deepest gratitude to the Serbian Ministry of Science and Technological Development for Grant NO175014, which was one of the sources of financial support for this study.

\section{REFERENCES}

1. Dagher L, Moore K. The hepatorenal syndrome. Gut 2001;49(5): 729-37.

2. Arroyo V, Torre A, Guevara M. Recent advances in hepatorenal syndrome. Trop Gastroenterol 2005; 26(1): 13-20. 
3. Barada K. Hepatorenal syndrome: pathogenesis and novel pharmacological targets. Curr Opin Pharmacol 2004; 4(2):189-97.

4. Arroyo V, Guevara M, Gines P. Hepatorenal syndrome in cirrhosis: pathogenesis and treatment. Gastroenterology 2002; 122(6): 1658-76.

5. Blaise P, Moonen M, Rorive G. Update on hepatorenal syndrome. Nephrologie 2002; 23(1): 11-7. (French)

6. Kramer L, Horl WH. Hepatorenal syndrome. Semin Nephrol 2002; 22(4): 290-301.

7. Biswas KD, Jain AK. Hepatorenal syndrome. Review. Tropical Gastroenterology 2002; 23(3):113-6.

8. Gentilini P, Vizzutti F, Gentilini A, Zipoli M, Foschi M, Romanelli RG. Update on ascites and hepatorenal syndrome. Review. Digestive \& Liver Disease 2002; 34(8):592-605.

9. Arroyo V, Gines P, Gerbes AL, Dudley FJ, Gentilini P, Laffi G. Definition and diagnostic criteria of refractory ascites and hepatorenal syndrome in cirrhosis. International Ascites Club. Hepatology 1996; 23:164-76.

10. Ginès A, Escorsell A, Ginès P, Saló J, Jiménez W, Inglada L, Navasa M, Clària J, Rimola A, Arroyo V. Incidence, predictive factors, and prognosis of the hepatorenal syndrome in cirrhosis with ascites. Gastroenterology. 1993;105:229-236.

11. Garcia-Tsao G, Parikh CR, Viola A: Acute kidney injury in cirrhosis. Hepatology 2008; 48: 2064-2077.

12. Gines P, Guevara M, Arroyo V, Rodes J. Hepatorenal syndrome. Lancet 2003; 362(9398): 1819-27.

13. Cholongitas E, Senzolo M, Patch D, Shaw S, O'Beirne J, Burroughs AK: Cirrhotics admitted to intensive care unit: the impact of acute renal failure on mortality. Eur J Gastroenterol Hepatol 2009; 21: 744-750.

14. Gines P: Pharmacological management of hepatorenal syndrome: lessons from non-responders. J Hepatol 2011; 55: 268-269.

15. Gluud LL, Christensen K, Christensen E, Krag A: Systematic review of randomized trials on vasoconstrictor drugs for hepatorenal syndrome. Hepatology 2010; 51: 576-584.

16. Petrović D.Hepato-renalni sindrom: etiopatogeneza, dijagnostika I lečenje. U: Akutno oštećenje bubrega u kliničkoj praksi. Petrović D.Ed.Kragujevac:Interprint 2013:277-84

17. Salerno F, Gerbes A, Gines P, Wong F, Arroyo V: Diagnosis, prevention and treatment of hepatorenal syndrome in cirrhosis. Gut 2007;56: 1310-1318.

18. Alessandria C, Ozdogan O, Guevara M, Restuccia T, Jimenez W, Arroyo V, Rodes J, Gines P: Meld score and clinical type predict prognosis in hepatorenal syndrome: relevance to liver transplantation. Hepatology 2005; 41: 1282-1289.

19. Moreau R, Lebrec D. Acute renal failure in patients with cirrhosis: perspectives in the age of MELD. Hepatology. 2003;16:233-243.

20. Angeli P, Morando F, Cavallin M, Piano S. Hepatorenal syndrome. Contrib Nephrol. 2011;174:46-55.
21. Cardenas A, Gines P, Rodes J. Renal complications. In: Schiff ER, Sorrekk MF, Maddrey WC, editors. Schiff 's Diseases of the Liver. Philadelphia: Lippincott Williams \& Wilkins: A Wolters Kluwer Company; 2003. p.497-509

22. Petrović D.Akutno oštećenje bubrega; etiologija, dijagnostika i lečenje. Medicinska istraživanja 2011; 45(3):7-13

23. Nadim MK, Kellum JA, Davenport A, Wong F, Davis C, Pannu N, Tolwani A, Bellomo R, Genyk Y. Hepatorenal syndrome: the $8^{\text {th }}$ International Consensus Conference of the Acute Dialysis Quality Initiative Group. Crit Care. 2012;16:R23.

24. Gines P, Schrier RW. Renal failure in cirrhosis. N Engl J Med. 2009;16:1279-1290.

25. Angeli P, Wong F, Watson H. Hyponatremia in cirrhosis: results of a patient population survey. Hepatology. 2006;44:1535-1542.

26. Sherlock S, Dooley J. Ascites. In: Sherlock S, Dooley J, editors. Diseases of the Liver and Biliary System. 11th ed. Oxford, UK: Blackwell Publishing Company; 2002. p.127-46.

27. Gines P, Berl T, Bernardi M. Hyponatremia in cirrhosis: from pathogenesis to treatment. Hepatology. 1998;28:851-864

28. Amodio P, Del Piccolo F, Petteno E. Prevalence and prognostic value of quantified electroencephalogram alterations in cirrhotic patients. J Hepatol. 2001;35:37-45.

29. Heuman DM, Abou-Assi SG, Habib A. Persistent ascites and low serum sodium identify patients with cirrhosis and low MELD scores who are at high risk for early death. Hepatology. 2004;40:802-810.

30. Konstam MA, Ghiorghiade M, Burnett JC Jr. Effects of oral tolvaptan in patients hospitalized for worsening heart failure: the EVEREST Outcome Trial. LAMA 2007;297:1319-1331.

31. Sort P, Navasa M, Arroyo V, Aldeguer X, Planas R, Ruiz del Arbol L, et al. Effect of intravenous albumin on renal impairment and mortality in patients with cirrhosis and spontaneous bacterial peritonitis. N Engl J Med 1999;341:403-409.

32. Fasolato S, Angeli P, Dallagnese L, Maresio G, Zola E, Mazza E, et al. Renal failure and bacterial infections in patients with cirrhosis: epidemiology and clinical features. Hepatology 2007;45:223-229.

33. Lukić S, Petrović D. Prevencija akutnog oštećenja bubrega u jedinicama intenzivnog lečenja. Med Čas 2012; 46(2):100-4.

34. Gonwa TA, Morris CA, Goldstein RM, Husberg BS, Klintmalm GB. Long-term survival and renal function following liver transplantation in patients with and without hepatorenal syndrome - experience in 300 patients. Transplantation 1991;51:428-430.

35. Lafayette RA, Paré G, Schmid CH, King AJ, Rohrer RJ, Nasraway SA. Pretransplant renal dysfunction predicts poorer outcome in liver transplantation. Clin Nephrol. 1997;48:159-164. 
36. Gonwa TA, Klintmalm GB, Levy M, Jennings LS, Goldstein RM, Husberg BS. Impact of pretransplant renal function on survival after liver transplantation. Transplantation. 1995;59:361-365.

37. Schepke M, Appenrodt B, Heller J, Zielinski J, Sauerbruch T. Prognostic factors for patients with cirrhosis and kidney dysfunction in the era of MELD: results of a prospective study. Liver Int 2006;26:834-839.

38. Olivera-Martinez M, Sayles H, Vivekanandan R, D' Souza S, Florescu MC. Hepatorenal syndrome: are we missing some prognostic factors? Dig Dis Sci 2012 $57(1): 210-4$.

39. Le Moine O. Hepatorenal syndrome - outcome after liver transplantation. Nephrol Dial Transplant 1998; 13(1):20-2.

40. Piano S, Morando F, Fasolato S, Cavallin M, Boscato N, Boccagni P, Zanus G, Cillo U, Gatta A, Angeli P. Continuous recurrence of type 1 hepatorenal syndrome and long-term treatment with terlipressin and albumin: a new exception to MELD score in the allocation system to liver transplantation? J Hepatol. 2011;55:491-496.

41. Caraceni P, Santi L, Mirici F, Montanari G, Bevilacqua V, Pinna AD, Bernardi M. Long-term treatment of hepatorenal syndrome as a bridge to liver transplantation. Dig Liver Dis. 2011;43:242-245

42. Saló J, Ginès A, Quer JC, Fernández-Esparrach G, Guevara $\mathrm{M}$, Ginès $\mathrm{P}$, Bataller R, Planas R, Jiménez W, Arroyo V, et al. Renal and neurohormonal changes following simultaneous administration of systemic vasoconstrictors and dopamine or prostacyclin in cirrhotic patients with hepatorenal syndrome. J Hepatol 1996;25:916-923.

43. European Association for the Study of the Liver: EASL clinical practice guidelines on the management of ascites, spontaneous bacterial peritonitis, and hepatorenal syndrome in cirrhosis. J Hepatol 2010; 53: 397-417.
44. Runyon BA: Management of adult patients with ascites due to cirrhosis: an update. Hepatology 2009; 49: 2087-2107.

45. Moreau R, Lebrec D. The use of vasoconstrictors in patients with cirrhosis: type 1 HRS and beyond. Hepatology 2006;43:385-394.

46. Maddukuri G, Cai CX, Munigala S, Mohammadi F, Zhang Z. Targeting an Early and Substantial Increase in Mean Arterial Pressure Is Critical in the Management of Type 1 Hepatorenal Syndrome: A Combined Retrospective and Pilot Study.Dig Dis Sci 2013.

47. Martin L, Lahi M, Pepin MN, Guevara M, et al. Terlipressin and albúmina vs albúmina in patients with cirrhosis and hepatorenal syndrome: a randomized study. Gastroenterology 2008;134:1352-1359.

48. Alessandria C, Venon WD, Marzano A, Barletti C, Fadda M, Rizzetto M. Renal failure in cirrhotic patients: role of terlipressin in clinical approach to hepatorenal syndrome type 2. Eur J Gastroenterol Hepatol 2002;47:401-404.

49. Rajekar H, Chawla Y. Terlipressin in hepatorenal syndrome: Evidence for present indications. J Gastroenterol Hepatol. 2011;26 Suppl 1:109-114.

50. Wong F, Pantea L, Sniderman K. Midodrine, octreotide, albumin, and TIPS in selected patients with cirrhosis and type 1 hepatorenal syndrome. Hepatology 2004;40:55-64.

51. Rössle M, Gerbes AL. TIPS for the treatment of refractory ascites, hepatorenal syndrome and hepatic hydrothorax: a critical update. Gut 2010;59:988-1000.

52. Testino G, Ferro C, Sumberaz A, Messa P, Morelli N, Guadagni B, Ardizzone G, Valente U. Type-2 hepatorenal syndrome and refractory ascites: role of transjugular intrahepatic portosystemic stent-shunt in eighteen patients with advanced cirrhosis awaiting orthotopic liver transplantation. Hepatogastroenterology 2003;50:1753-1755. 